April 7, 2020

\title{
CDFIs Can Make the SBA PPP Loan Program Work for Smaller, Minority-Owned, and Women-Owned, Small Businesses
}

\section{Eric Hangen and Michael Swack}

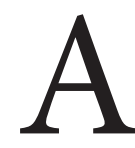

s currently being implemented by the Small

Business Administration (SBA), the loans

made available through the $\$ 349$ billion

Paycheck Protection Program (PPP), part of the

CARES Act recently enacted to address the COVID-19

crisis, are likely to significantly bypass smaller small

businesses and those that are minority- or women-

owned. The problem is that the SBA is running the program through banks that are existing SBA lenders, and many of these banks are choosing to serve only customers with existing business accounts and loans. This will exclude the many small businesses not currently served by SBA Lenders-disproportionately smaller, minority-owned, and women-owned businesses. Even if the SBA expands the program to include all federally insured depository institutions, most of these institutions are not well-positioned to serve this large group of firms that are critical to the American economy. An effective way to reach these businesses is to allow certified Community Development Financial Institutions (CDFIs) to disburse SBA PPP loans, and, going beyond PPP loans, to provide special funding that they can deploy to hard-hit communities through other loans and investments.

Small, women-owned, and minority-owned businesses are a critical part of the American economy:

- Sixty-two percent of all business establishments in the United States have fewer than 5 employees. Together they comprise 3.7 million firms, employing 5.9 million people (source: 2016 County Business Patterns data).

- There are almost a million $(996,248)$ minorityowned employer firms in the United States, and over a million $(1,118,863)$ women-owned employer firms (source: 2015 Annual Survey of Entrepreneurs).

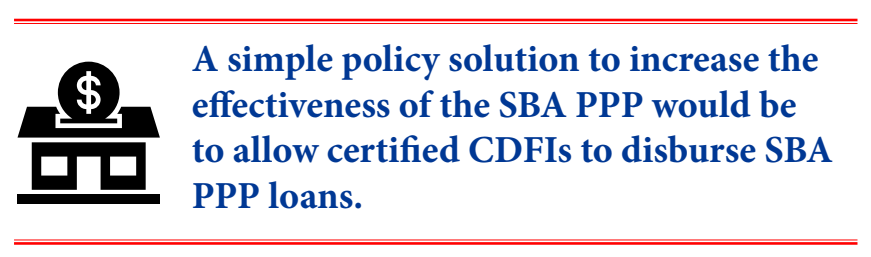

- CDFIs are on the front lines of serving microbusinesses (less than 10 employees) in rural and urban communities nationally. Estimates of the numbers are 2.9 million businesses and 8.7 million jobs in this sector (source: 2020 Brookings report "How local leaders can stave off a small business collapse from COVID-19").

A substantial literature documents that small firms, minority-owned firms, and women-owned firms struggle to access bank financing. ${ }^{1}$ Overall, the volume of bank loans under $\$ 100,000$ to small businesses has declined by 48 percent from 2007 to 2018 (source: analysis of FFIEC CRA lending data). Instead, these businesses have been increasingly reliant on high-priced financing from credit cards or online "fintech" lenders, as well as CDFIs. As a result, few of these firms have existing borrowing relationships with the banks who have been selected to administer the SBA Paycheck Protection Program. These dynamics raise serious questions about whether one of the most vulnerable sectors of the U.S. economy will also miss out on the assistance it needs.

CDFIs provide an effective alternative route through which aid could be channeled to these businesses. From 2015 through 2017, CDFIs made over 31,000 loans to small businesses with 5 or fewer employees-and coupled this affordable financing with hands-on technical assistance to help businesses succeed. A previous Carsey School of Public Policy evaluation of the CDFI program found that CDFIs 
targeted over 80 percent of their loans to businesses that were either minority-owned, women-owned, and/ or located in economically distressed areas-ranging from rural to urban. The same evaluation also found that during the last recession, just as mainstream financial institutions pulled back from lending, CDFIs actually "stepped into the breach" and significantly grew their lending activity. The CDFIs were able to do this while remaining financially strong.

A simple policy solution to increase the effectiveness of the SBA PPP would be to allow certified CDFIs to disburse SBA PPP loans. This would allow CDFIs to serve community-oriented small businesses, helping them to continue to employ thousands of peoplesomething that they will not be able to do without assistance. Without this bridge to a post-COVID-19 existence many of these businesses will fail, removing important pillars on which their communities depend.

A further step, beyond the SBA PPP program, would be to provide special funding that CDFIs could target to particularly hard-hit, hard-to-reach, communitiesirrespective of firm size. Only recent grant awardees are required to report data to the CDFI fund, but these data suggest that CDFIs could easily deploy over $\$ 10$ billion in loans to businesses, nonprofits, and low-income communities. The $235 \mathrm{CDFIs}$ reporting data to the CDFI fund-just a fraction of the over 1,000 CDFIs across the country-made over $\$ 7.5$ billion in loans in 2017, the most recent year for which data are available (source: CDFI Fund data). That $\$ 10$ billion dollars, or more, would provide assistance to small businesses not well served by the current program, and also stabilize a full range of ventures and projects from affordable housing to schools, health clinics, and community facilities.

\section{Endnotes}

1. See, for example:

https://www.mbda.gov/sites/mbda.gov/files/migrated/filesattachments/DisparitiesinCapitalAccessReport.pdf

https://www.nwbc.gov/2018/03/01/the-latest-report-fromthe-national-womens-business-council-on-women-busi-

ness-owners-access-to-capital/

https://ilsr.org/rule/financing-local-businesses/

\section{About the Authors}

Eric Hangen is a senior research fellow at the Center for Impact Finance at the Carsey School of Public Policy.

Michael Swack is the director of the Center for Impact Finance at the Carsey School of Public Policy with a joint appointment at the Peter T. Paul College of Business and Economics at the University of New Hampshire.

For more information, contact Michael Swack at michael.swack@unh.edu.

\title{
TI University of New Hampshire Carsey School of Public Policy
}

The Carsey School of Public Policy at the University of New Hampshire is nationally recognized for its research, policy education, and engagement. The school takes on the pressing issues of the twenty-first century, striving for innovative, responsive, and equitable solutions.

\author{
Huddleston Hall • 73 Main Street • Durham, NH 03824 \\ (603) 862-2821 \\ TTY UsERS: DIAL 7-1-1 OR 1-800-735-2964 (RELAY N.H.) \\ carsey.unh.edu
}

